\title{
New records and species of Canalisporium (Hyphomycetes), with a revision of the genus
}

\author{
T.K. Goh, W. H. Ho, K.D. Myde, S.P. Whitton, and T.
}

\begin{abstract}
Three new species of Canalsponim, namely Canalisporitm exigum Goh \& $\mathrm{K} . \mathrm{D}$. Hyde, Conalisporim kenyense Goh, W.H. Ho \& K.D. Hyde, and Conalisporizm pallow Goh, W.H. Ho \& K.D. Hyde, are descrbed and Illustrated. New records of Candisponim cawbense, Candisponizn pulchm, and Candisporm elegans, are given. They are also inustrated from fresh material and briefly discussed. Comparisons of conidial momphology of all species from different localities are made and a key to he species of the genus is provided.
\end{abstract}

Key words: Berkleaswitn, denatiaceous hyphonycetes, freshwater fungi, lignicolous fungi, systematics.

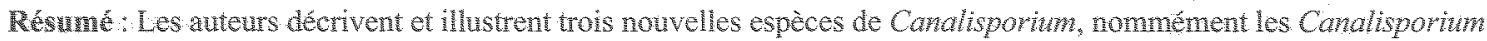

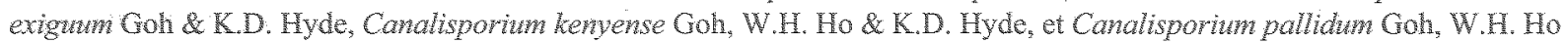
\& K.D. Hyde. Is présententegalenent de nouvelles mentions pour les Canalisporim canbense, Canalsporim pulchrum, et

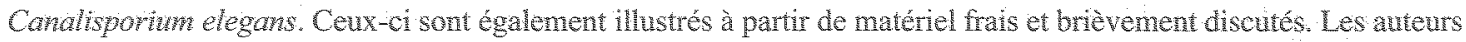
comparent la morphologie conidiale de toutes les éspèces provenant de localtés diverses et présentent une clé pontr les espèces de co gente.

Mots cles: Berkleasminm, hyphomycètes dématies, champignons deav douce, champignons lignicoles, systénatique.

Traduit par la rédaction]

\section{Introduction}

The genus Candhpornm Nawawi \& Kuhwbwheen (1989) was introduced to accommodite Berleasmin canbense Hol. Jech. \& Morcado, Berklewsmin pulchmm Wol.Jech. \& Mercado (Molubovar-Jochovân and Mercado Sierra 1984), and a mint new species, Canalisportum elegans Nawawi \& Kuthibuheen (1989). Conidia of Camalsponm species are muniform; however, they difer from those of Berleasmin species in being fattened dorsiventrally, comprising a single layer of regularly arranged cells, which are supported by a small, thin-walled, cunoform, pale basal cell.

In Canalisporim carbense (Hol.Jech. \& Mercado) Nawawi \& Kuthub, conidia possess a single column of vertical septa, and $3-6$ equally spaced rows of transverse septa. In $\mathrm{Ca}$ nahpormm mulchm (Hol.Joch. \& Mercado) Nawawi \& Kuthub., condia have 2 columns of vertical septa, and 46 rows of transverse septa, while in $C$ elegans, conidia possess 4-5 columins of vertical septa, and $5-7$ rows of tansverse septa (Nawawi and Kuthubutheen 1989). These conidia, the septa of Which usually become progressively darker with maturity, resomble cockroal cocoons. The most striking feature of the conidia, as suggested by the generic etymology, is the presence of narrow canals connecting adjacent cell lumens. Pach of

Received Aprl 23, 1997

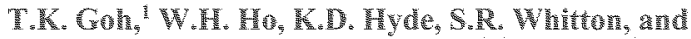
T.E. Umall. Department of Ecology and Biodiversity, The University of Hong Kong, Pokfuan Roa, Hong Kong.

Auhor to whom all comespondence should be addressed. e-mail: tkgon@hkuchkmh these canals is sumonded by a marked ring of pigmentation, visble as a circular dise in lateral view or a barrel shape in dorsiventral view. Conidia in species of Berkleasmum (Moore 1959; Elis 1971 , 1976) are distincty cylindrical with ran domly ananged septa and lack connecting cands between the cell lumens. The teloomonphs of Canahponim species are presently unkwown.

Candisporim species are common saprophytes on roten wood, and have a pantropical distribution. The genus has been recorded in Cuba (Holubová-Jechova and Meroado Sierta 1984), India (Rao and de Hoog 1986), Kenya (Kirk 1985) Malaysia (Nawawi and Kuthubheen 1989), wawan (Mat sushma 1987), and Uganda (Matsushma 1987). During our investigations of microfungi on submerged wood and other decaying plant material in the tropics, we have obtaned several collections of C carbense, C. pulchwm, and C. elegms. In one noth Quecnsland collection, the condia were similat to $\mathrm{C}$. carbense, but were distinctly smaller. We thereiore de scribe this fungus here as Canalisporim exigum sp. nov. The conidid sizes of $\mathrm{C}$ cambense, $\mathrm{C}$. pulchm, and $\mathrm{C}$. elegans collected from various localities are compared in Tables 1,2 and 3 and each species is illustrated and briefly discussed.

The bye material of $D$. pulchmm (sensu Lohubová-Jechova and Mercado Siema $1984 ;$ PRM 831528 ) has conidia hat ate evenly pigmented, whin a single, paler basal cell. We have examined a collection of "Rerkleasminm pulchwm" (sensu Kirk 1985: Wh 285428a) from Kenya. The condia in this collection were typical of Canalisporim, bu do not contom to the above species, as the conidial body is bome on a hom zontal row of three, thinwalled, subhyme, small basal cells. Each honzontal row of cells differs clearly in wall thickess and pigmentation from the next row and the apical rows are 


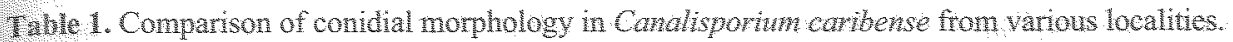

\begin{tabular}{|c|c|c|c|c|c|c|c|c|c|}
\hline loodity & $\begin{array}{c}\text { Herbarium } \\
\text { No. }\end{array}$ & Habitar & $\begin{array}{c}\text { Lengh } \\
\text { (um) }\end{array}$ & $\begin{array}{l}\text { Widh } \\
\text { (um) }\end{array}$ & $\begin{array}{c}\text { Latera } \\
\text { hokness } \\
\text { (um }\end{array}$ & $\begin{array}{l}\text { No. of } \\
\text { columins of } \\
\text { vertical sopta }\end{array}$ & $\begin{array}{c}\text { No. on pows } \\
\text { of thansverse } \\
\text { septa }\end{array}$ & $\begin{array}{l}\text { No. or } \\
\text { cels in } \\
\text { apical row }\end{array}$ & $\begin{array}{l}\text { No.of } \\
\text { cels per } \\
\text { conidum }\end{array}$ \\
\hline \multirow[t]{4}{*}{ Erruer } & HKUN 2910 & submorged wood & $26-43$ & $16-26$ & - & 1 & 36 & $(1)^{2}$ & $8-14$ \\
\hline & HKUN 4902 & Freycinetia sp. & $32-38$ & $20-24$ & 1012.5 & 1 & 34 & 2 & $9-13$ \\
\hline & HKUM 4903 & Froycinetiasp & $35-51$ & $22-27$ & $\cdots$ & 1 & $5-6$ & 2 & $11-17$ \\
\hline & HKUMAOOA & Pandanws sp. & $28-38$ & $20-24$ & - & 1. & $3-4$ & 2 & $9-13$ \\
\hline Cuts & PRM 831526 & roten branch & 2545 & $15-29$ & $9.5-16$ & 1 & 36 & 2 & $9-15$ \\
\hline \multirow[t]{2}{*}{ Hore Kong } & mKUN 334 & subnerged wood & 3238 & 2229 & $10-12$ & 1 & $3-5$ & 2 & $9-13$ \\
\hline & $H K \cup M 3401$ & Bawbusasp & $25-30$ & $15-20$ & $10-12$ & 1 & 34 & 2 & $9-11$ \\
\hline Reiva & $1 M 284792 a$ & anmonom so & $24-36$ & $16-22$ & $8-12$ & 1 & 56 & 2 & $13-15$ \\
\hline \multirow[t]{2}{*}{ Matrysta } & HN 326001 & submerged Woud & 284 & 2128 & $10-14$ & 1 & 36 & 2 & $9-15$ \\
\hline & $\mathrm{HWU} 2003$ & submerged wood & 21,36 & $16-24$ & +8 & 1 & $3-5$ & 2 & $9-13$ \\
\hline \multirow[t]{2}{*}{ Phinpunes } & HWUN 4905 & Pandanus sp & $23-32$ & $17-20$ & $10-125$ & 1 & 34 & 2 & $9-13$ \\
\hline & I KU M 4006 & Hermenses & $23-34$ & $19-22$ & $10,12.5$ & 1 & 24 & 2 & $7-13$ \\
\hline Trwhn & MOrToll & dead palm rachis & 2230 & 1518 & 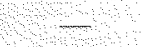 & 1 & 45 & 2 & $11-13$ \\
\hline Thisuda & $\mathrm{MHC} 327$ & roten woot & $24-42$ & $16-22$ & $10+2$ & 1 & $5-6$ & 2 & $13-15$ \\
\hline Vortuntur & $N K O M 1001$ & Pandanusp. & $24-32$ & $15-19$ & $9-12$ & 1 & 3 & 2 & $9-11$ \\
\hline
\end{tabular}

Theludes basal odl

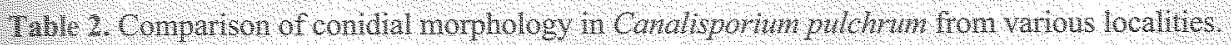

\begin{tabular}{|c|c|c|c|c|c|c|c|c|c|}
\hline Puratrits & $\begin{array}{c}\text { Hebarum } \\
\mathrm{No}\end{array}$ & Habiat & $\begin{array}{l}\text { ensh } \\
\text { (unn) }\end{array}$ & $\begin{array}{l}\text { What } \\
(\mathrm{mln})\end{array}$ & $\begin{array}{l}\text { Latents } \\
\text { twokness } \\
\text { (mm) }\end{array}$ & $\begin{array}{c}\text { No of } \\
\text { commer of } \\
\text { vertical sepera }\end{array}$ & $\begin{array}{l}\text { No of rovs } \\
\text { ofrans verse } \\
\text { sopha }\end{array}$ & $\begin{array}{l}\text { No ot } \\
\text { ocls } \\
\text { anch }\end{array}$ & $\begin{array}{l}\text { No. of } \\
\text { cells per } \\
\text { conidin }\end{array}$ \\
\hline Aristuras & HOUM 3192 & subnerged vood & $30-42$ & $20-22$ & $12-13$ & 2 & 43 & 13 & $14-17$ \\
\hline Hrunests & HKUN2911 & submerged wood & 2563 & 1625 & 1016 & 2 & $3-9$ & $1-3$ & $1 \mid-31$ \\
\hline rubs & PRN 831566 & Toten wood & 316 & $23-32$ & $13-16$ & 2 & $3+7$ & $1+3$ & $13-21$ \\
\hline Who lang & WOWHAl & subntrorged wood & $35-44$ & $20-23$ & 1417 & 2 & 36 & 1,3 & $17-22$ \\
\hline (riserid & $0 B S H 3852$ & rotwh wood & 2850 & 2029 & 1517 & 2 & 36 & mostiy I & $11-20$ \\
\hline Whrosta & Wh 326602 & submerged wood: & $36-52$ & $22-27$ & $2-15$ & 2 & 47 & 1-3 & 1425 \\
\hline
\end{tabular}

Hivudes bisalcell

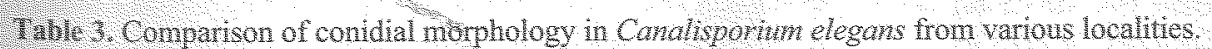

\begin{tabular}{|c|c|c|c|c|c|c|c|c|c|}
\hline Inodivy & 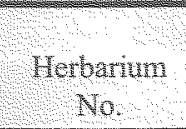 & Mabitat & $\begin{array}{l}\text { Iemgth } \\
\text { (Mm) }\end{array}$ & $\begin{array}{l}\text { Width } \\
\text { (um }\end{array}$ & $\begin{array}{l}\text { Lateral } \\
\text { Howness } \\
\text { (um) }\end{array}$ & $\begin{array}{l}\text { No on } \\
\text { columins of } \\
\text { verthal sents }\end{array}$ & $\begin{array}{l}\text { No of roks } \\
\text { of thansverse } \\
\text { septa }\end{array}$ & $\begin{array}{l}\text { No of } \\
\text { cels in } \\
\text { apical row }\end{array}$ & $\begin{array}{l}\text { No. of } \\
\text { colls per } \\
\text { conidium }\end{array}$ \\
\hline \multirow{3}{*}{ 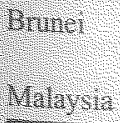 } & HRUM 4007 & Freycineth $\mathrm{se}$. & $37-48$ & $25-38$ & & $3-4$ & $5-1$ & 15 & $27-41$ \\
\hline & THYN 2026 & sumerged wood & $38-58$ & $25-35$ & $10-13$ & 45 & 68 & 145 & $26-36$ \\
\hline & Wh 30603 & submorged wood & 324 & $27-33$ & 1013 & $4-5$ & $5-7$ & $1<5$ & $26-35$ \\
\hline
\end{tabular}

Thelititer basil cell

Tharce har the basal rows Mhese differences have allso been Thmoned on by Rao and de (100g (1986) and Nawawi and

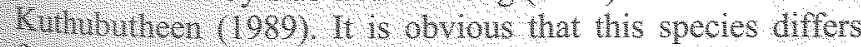
Ton $B$. jwhrm (sensu Nawaw and Kuthubutheen 1989 ) Thd I Is herchore desenbed here as Camalsponim kenyene (1) $(10)$

Wo luve collected a huther spectes from Wong Wong hat Wuerrowl resenbles C. carbense, but produces very pale fondra bastowh, hese conda possess a single colmm of Whit septa and 4 rows of wansverse septa $1 \mathrm{n}$ some of The condira, one or two central wows of cells noy possess $1-2$

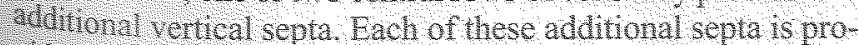

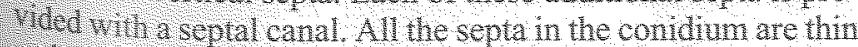

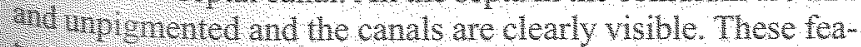

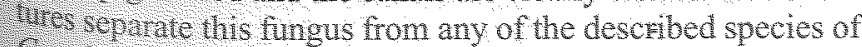
tw whom and is is therefore described here as Candis- pormm paldwn sp nov. Wht the additon of hree species, the gens Candwoowh now conststs of sx haxa. Wustations of condin mon varous collectons, drawn to the sane scale for companson, are provided (Figs. $49-63)$, as well as a key to the spectes of the genus.

\section{Taxonomy}

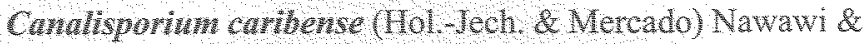
Tuthub. Mycotaxon, $34,49,1989$

Hgs: $1-11,49-56$

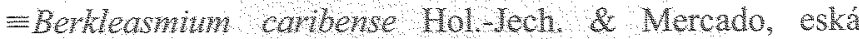
Mylol. $38: 99.1984$

SPECMENS EXAMND, BRUNE, Temburong, Batu Apoi Forest Reserve, Sungai Belalong, Kuala Belalong Field Studies 


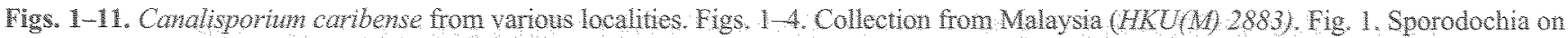
submerged wood Fig, 2. Squash moth of a portion of a sporododmun showing vesiculate condogenous hyphae and conida. Figs. 3 , 4 .

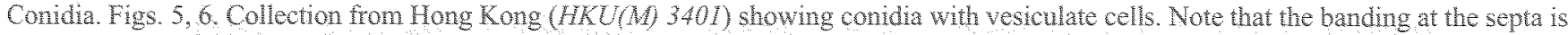
very broad in this collecton. Fig. 7 . Squash moun in sterle water showng condia and chans of vesiculate cells (HKU M 2910 , Brunei). Figs. 8-10. Condia (HKU(M) 2883 , Malaysia), wo in surface view and one in lateral view showing canals. Fig. 11 . High magnitication of a

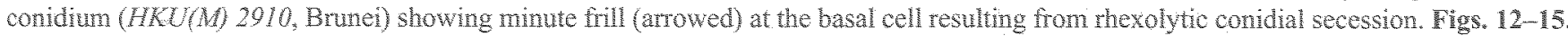

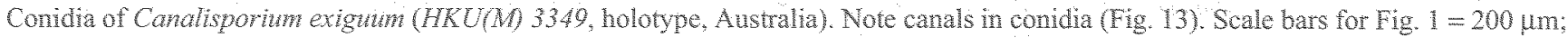
Figs. $2,7,12=20$ um; Figs. $3-6,8-11,13-15=10 \mu m$
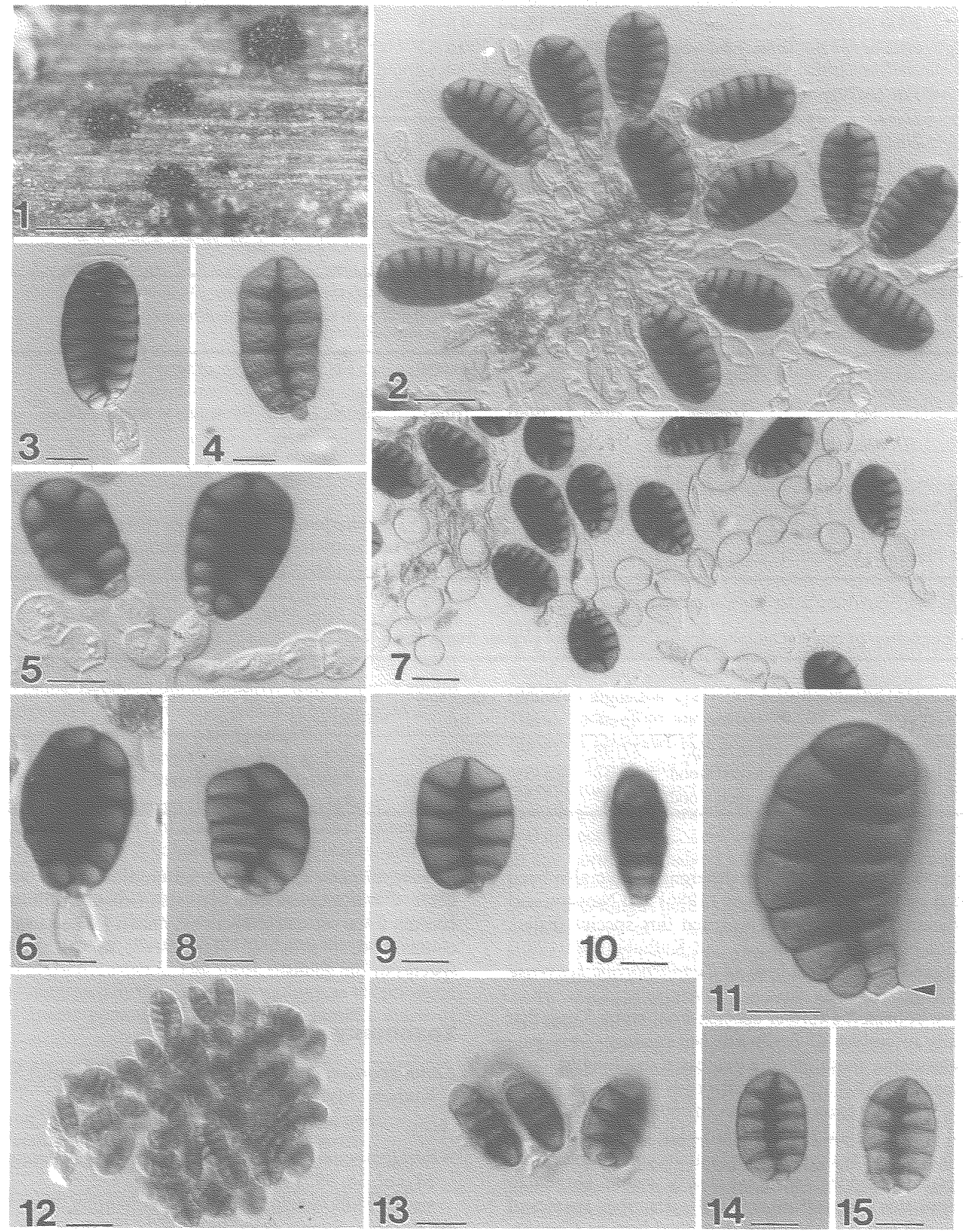
Certre, Sungai Sitam, on subnerged woot, 24 Oct. 1995

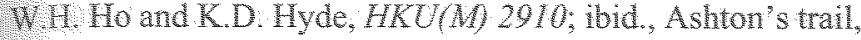
on decaying lea of Frevcinetia sp, 24 Oct. 1995, S.R. Whic-

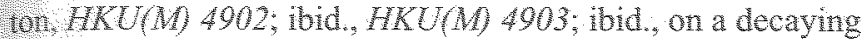
les of fandams sp, 25 Oct 1995, S.R. Whiton, HKV(M) 100, HONG KONG, New Temitories, Ta Po, Ta Po Kau Twhry Park, on a senescent cum of Bwhbsa sp. Jwhe 1995 ,

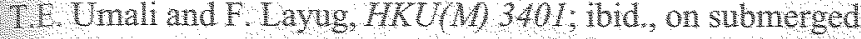

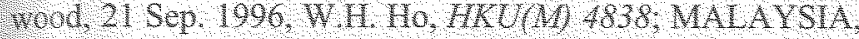
Kwha Lumpur State Negara, L pur Lenwng Nature Reserve,

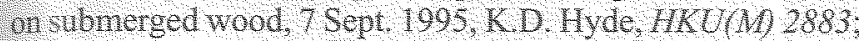

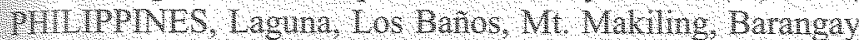

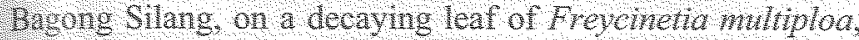

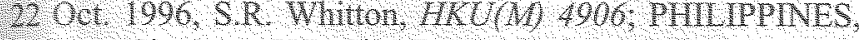
Quern, sinoloan, UP Site, Barangay Wagsaysay, on a de

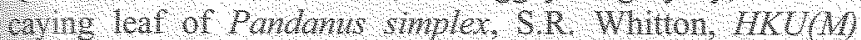
4005, VANUATU, Erate, near Bton, on a deeaving leaf of

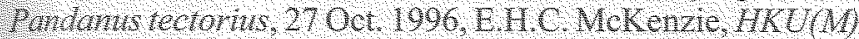
.1901

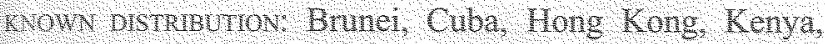
Malu via, Philipines, Twinan, Jganda, Vamant

Wores: The charaetensic dakened pgmentahon around he rent of he comdia lends lo be nher variable For example Wo ration s shown in wo of ow collectons. the conidia of

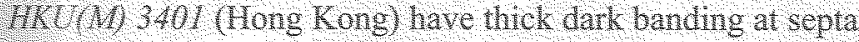
Pigs: 5, 6, 51, whoreas hose of HWOWM 2883 (Malaysia) lave comparanvely less pignentaton around the septa (Figs, 2, 4, 5). The canals are oren dificult to see in sur race Wew becanse of he dor kened plgnentaton; however, hey are homaly wible in lateral vew (Tigs. $10,53,55$ ). Most of the conitha from varous localines have hree rows of hansverse septa, ahough some nay have up to six rows Because of the Wration in he number of rows of hansverse seph, here is also it conesponding vanaton in eel number and size (This)

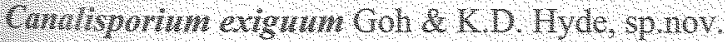

Tlgs, $2-15,57$

HT wowor exghm, lath smal, in reference to the size Whe onnta.

Sporodoena nunta, wsquo 35 um lata, ex condionhors ft usune 60 condis composita. Mycenmmex hyphs laevibus, If -2.5 un hais, composium Contolophora uscue $25 \mathrm{um}$ 16rist of $2-3,5$ un lab Conhom secessio rhexolytica. Goming in conspects superholahbus late ellusoldea vel oboYide, in conspectis laterahbus cylincrica vel clavata, pallo Tharebrumea vel pallide punceobrimea, mur forma $1825 \times 13-15 \times 58$ um, cun Candrophum canbense fintis sed parrora:

Mol OTPUS AUSTRAL A, nom Queendand, Aheron Ta Wlelands, Lake Barine, on submerged wood, 24 Apr, 1996 ,

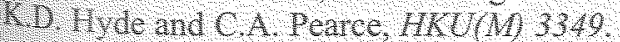

Sporodocha on natural substram punchlom, nume, fwateled, sramuar, black, gistening, 10 lo 35 un n dameth consismg of conklophores and no 10.60 condia. Nyce Wh hosil imnersed in the substratum, composed of Wratched, septate, sublyahe to pale brown, $1.5-25$ um wide, smooh lyphae. Conidiophores mictonematons or semthecroncmatous, hasciculate, simple or sparsely branched, Whooth hyane to subhyalne, up to 25 um long, $2-3.5 \mu \mathrm{m}$ wite. Condogenous cells integrated, teminal, deterninate, cyindrical or often becoming swollen. Condial secession

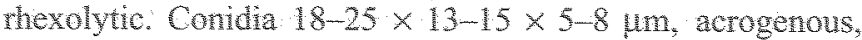
soltary, hatened, one cell thek, smooh, hick-walled, broady cllpsoida to obovoid in surface view, cylndrical to clavate in lateral view, pale olvaceous brown to pale pinkish brown, munfom, conprising of angle, stuint to slighty curved column of vertical septand $23(4)$ rows of transverse sepr, shghty constricted athe septa, septa becoming progressrvoly darker with condial nawnty, cel hmen conneeted by namow canals, basal cell subhyahe wo very pale brown, cunerom, $25-354 \mathrm{~m}$ wide, wh hinner wall

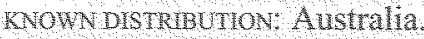

Nones Condia of C. exromm are smular to those of C. cariberse in having a single commor verted septa, athough they have fewer tows of runsverse septa $(1,0,2-3(4)$ in the fommer versus $3-6(-7)$ n he hter). The range of condial sizes of

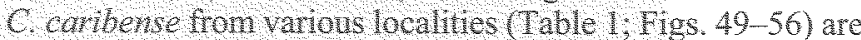
arget wan the condu of ( exgmm (Tig 57 ) from lake Barne, Australa, $n$ C exgmm, he raxinum lengh, widh, and herat holness of its conda are enal to the minmun of each respectre dinemsion of hose C cambense collecHons:

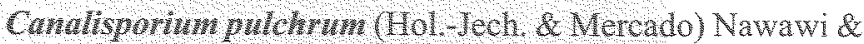
Whub, Nycotaxon, $34,481,1989$

19s. $16-22,61-63$

=Berkleammu pulowm Hol-Jech \& Mercado, eská Mykol, $38,101,1084$

SPECMENS EXAMED AUSTRAMA, noth Queensland, Aheron Tablelands, lake banne, on submetged wood, 24 An. 1906, K D Hyde and OA Pedrec, KKUM 3192. BRUNU1, Temburong, Ban hor Forest Reserve, Sungai BeIang, Kuna Betalong Hel Studes Centre, Sungai Sitam, on submerged wood, $240 \mathrm{ct}, 1995$, W N, 10 and $\mathrm{K} . \mathrm{D}$. Myde,

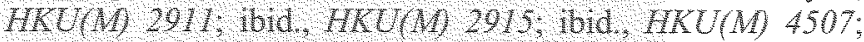
MONG KONG, Nev Tentortes, Plover Cove Reservoir, on submerged wood, 15 Nov 1906 , M. Wong and K. D. Hyde, 11001474

known Distubumox: Australa, Bune, Cwa, Hong Kong, MWa, Marasta

Nores In eomparing the frve colloctons of $C$. pulchm

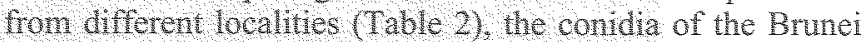
collecton $(h \times$ O $(1 / 2911)$ are relat vely larger and the species has he widest range in condral dmensons, induding number of cols per condinm (Figs, $16-18,21,62)$

Cwatspowm elegans Nawaw \& Kumub, Mycotaxon, 34 : 18,1989

Figs. 23-31,60

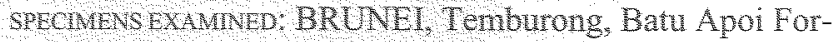
est Reserye, Sungat Belalong, Kuala Belalong Field Studies Cente, sungar Situm, on submerged wood, 24 Oct. 1995 .

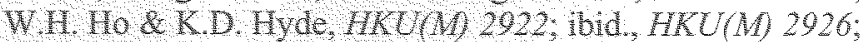
1bid. Astrons trat on a decaying leat of Freycinetia sp., 24 Oct 1995, SR. Whron, HOW/490\%.

KOW DISTREUTON Bmen Nalaysia:

NoTes This spetes is relat vely rate and it probably has a resnoted distribun In addion to he Malaysian specimen (MT 3 2603, Nawaw \& Kuthbuthen 989 , thee collections were obtamed from Brune: wo on submerged wood and the other from a decayng leat of Freychetia sp. (Table 3 ). The 


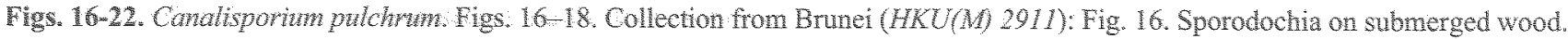
Fig. 17. Squash moun of a young sporochmm showing fascicte of condiogenous hyphas with swollen cells. Fig. 18. Contia. Figs. 19,20 . Collection from Australia (HKU M 3192). Conida. Note that banding in the septa is thiner in ths collection and canals are visible in Fig. 20 . Fig. 21. Collection from Brune (HKU/M 2911). Conidia. Note that the conidia have 8 rows of cells from this collection. Fig. 22. High

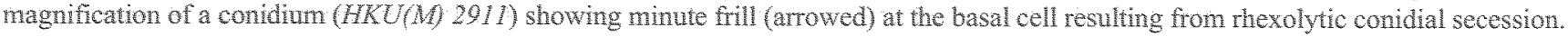
Scale bars for Fig. $16=200 \mu \mathrm{m}$, Fig. $19=20 \mu \mathrm{m}$ Figs. $17,18,20-22=10 \mu \mathrm{m}$.
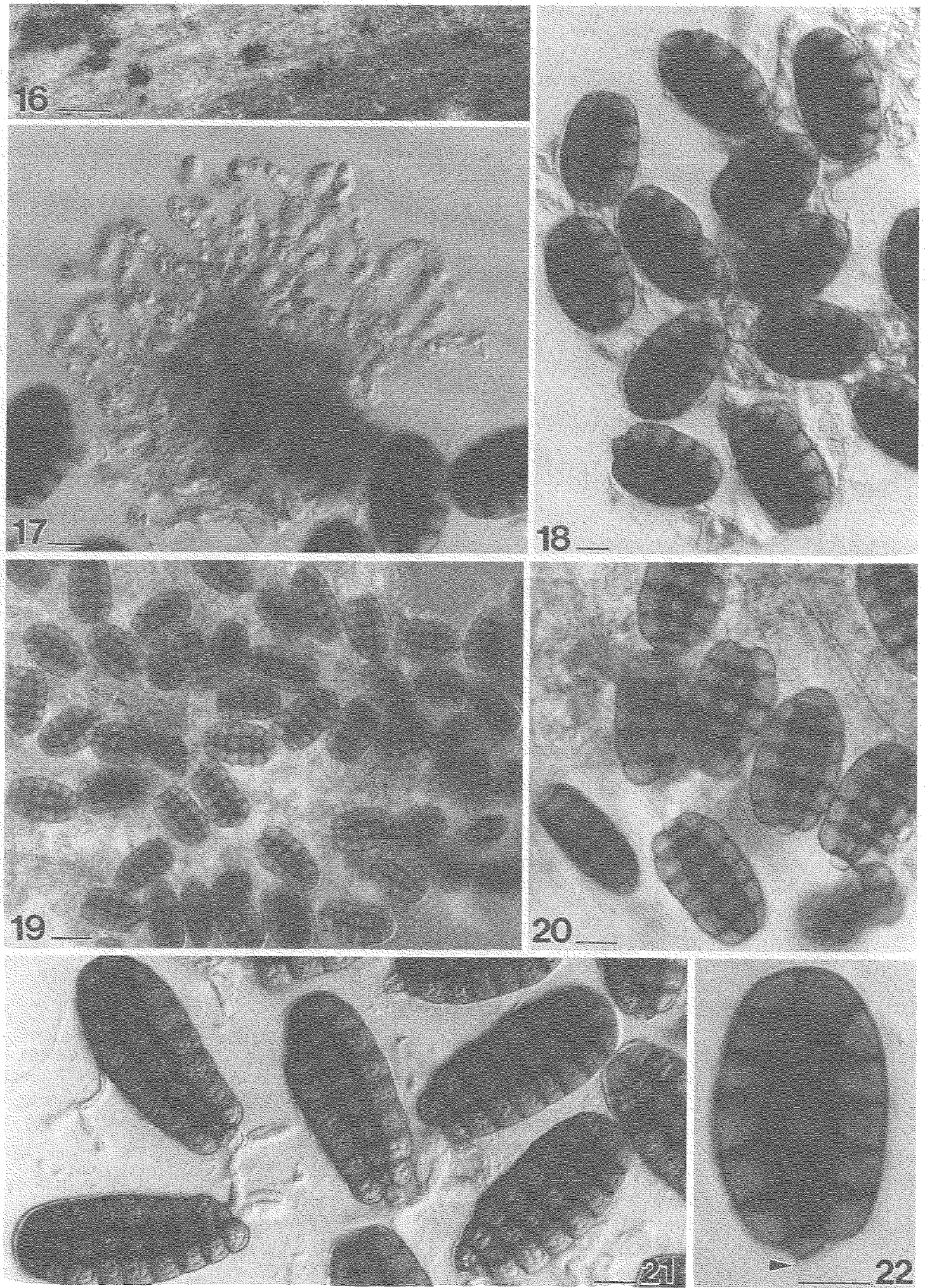


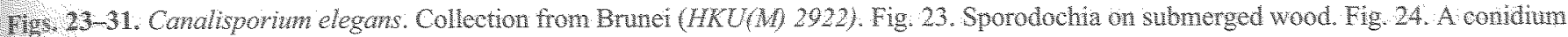

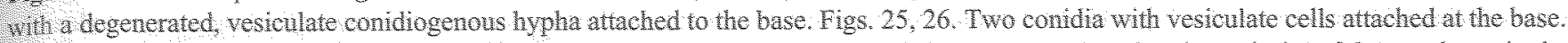

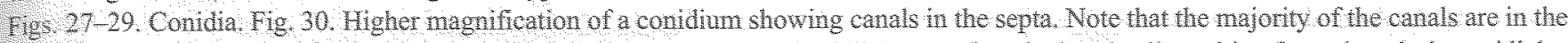

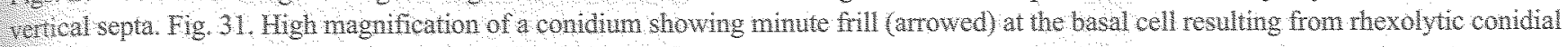
scosson. Scale bars for Fig. $23=200 \mathrm{Hm}, \mathrm{Fgs} .24-31=1 \mathrm{hm}$
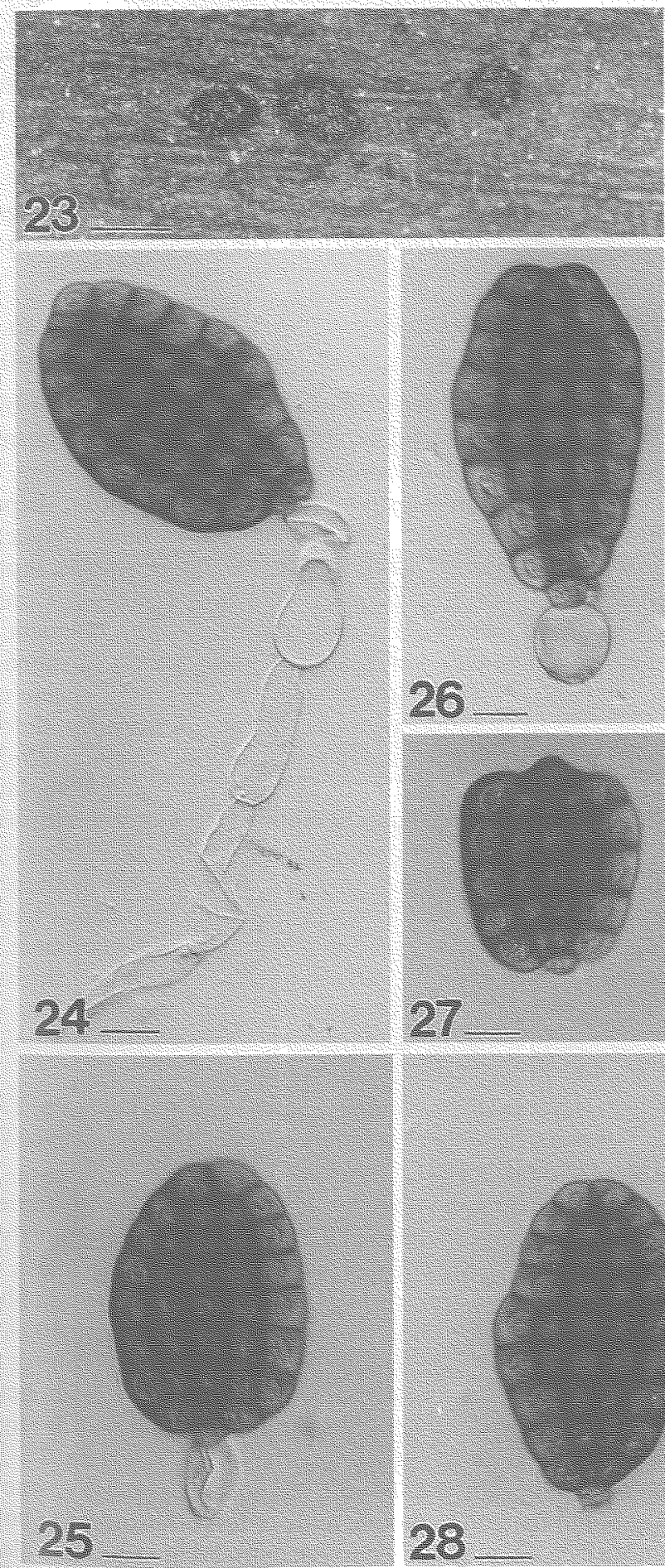
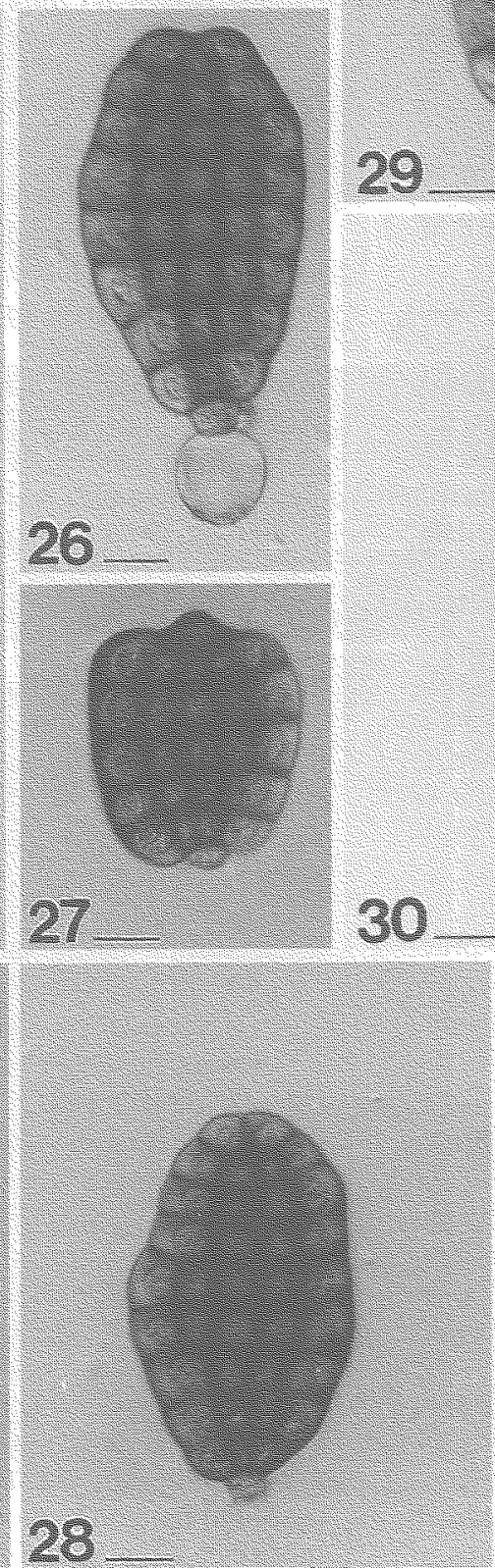
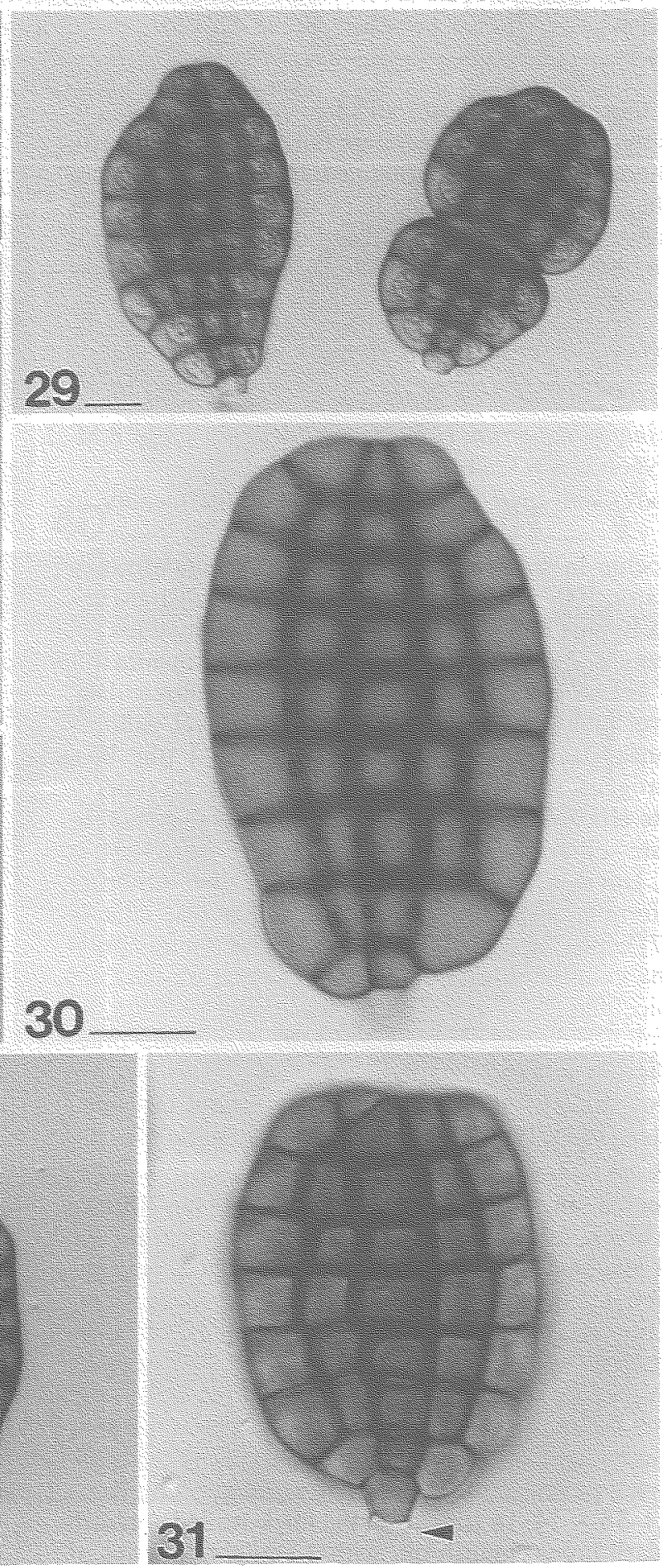


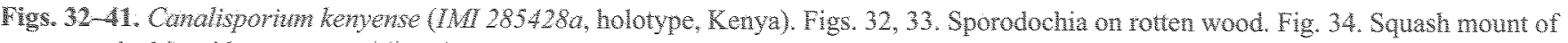
two sporodochia whth nature conidia. Figs. 35 40. Conida. Note that each conidum has three small cells in a row al the base and a single cell

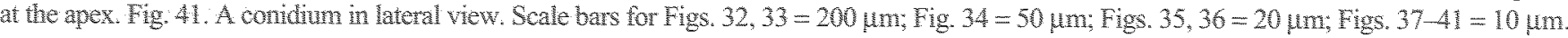

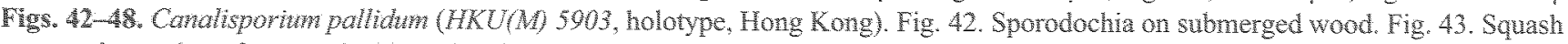
mount of a portion of a sporodochum showing condia. Note that some of he conida have an additional septa. Fig. 44 . A mass of conida with septa in focus. Fig. 45. The same mass of conidia with canals in focus. Note that each vertical septum is perforated by a canal, whereas only the transverse septa at the concave side of the condia possess canals. Fig. 46. Three condia, one in lateral view showing distinct canals. Note that the conidia in this species are pale and the septa are not banded. Figs, 47, 48. Conidogenous hyphae bearing mature conidia and a young

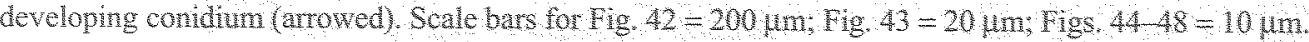

conidia of these collections are all Identicat in morphology. The canals that link the cell lumens ate farly distinct (Fig. 30), although the septa are darkly pigmented. Each vertical septum has a single canal, whereas along the transverse septa, canals are only present in the middle column of cells. Under the light microscope, these canals resemble the dolipore septa of many basidiomycetes.

Cantalisportuth henyense Goh, W.H.Ho \& K.D. Hyde, sp.nov. Figs. $32-41,59$

三Berkleasmium pulchrum Hol, Jech \& Mercado sensu P.M. Kirk, Mycotaxon, 23:313. 1985

ETMMOLOG: kenyense: in reference to the type locality in Kenya.

Sporodochia in substrato naturall dispersa, punctiformia, pulvinata, atra, $100-140 \mathrm{~mm}$ dian. Mycelum in substrato immersum, ex hyphis ramosis, septatis, laevibus, subhyalinis vel pallide brunneis, 2-3 um latis compositum. Conidiophora micronemata vel semi-macronemata, mononemata, fasciculata, simplicia vel interdun ramosa, septata, hyalina vel pallidissime brunnea, laevia, usque 25 um longa, $2-4$ um lata. Conidia acrogena, solitaria, complanata, in conspectis superficialibus late ellipsoidea vel pyriforma, in conspectis lateralibus angiste ellipsoidea vel clavata, $3456 \times 24-34 \times$ 14-18 $\mu \mathrm{m}$, laevia, crassitunicata, rubrobrunnea vel atrobrunnea, muriformia, cum septis longitudinalibus biserialis et $(3-) 4-5(-7)$ septis transversis in ordinem, atris, crassis praedita, lumina cellularum canaliculis connexa sed obscura, ad apicem unicellua $(9-15 \times 5-7 \mathrm{~mm}$ ) teminaliter praedita, ad basem tricellulae parvae $(2-3 \times 1.5-2 \mathrm{~mm})$ in ordinem praedita $_{\text {s }}$ conidionum secessio thexolytica.

Holotypus: KENYA, Mt Kenya, Castle Forest, on rotten wood, 25 Jan. 1984, P.M Krnk 1593a, IMI 285428 a.

IsoTypUs: $H K U$ M 3350 , slides.

Sporodochia on natural substrate scattered, punctiform, pulvinate, black, $100-140$ um in diameter Mycelium inmersed in the substrate, composed of branched, septate, smooth, subhyaline to pale brown, $2-3$ un wide hyphae. Conidiophores micronematous or semi-macronematous, mononematous, fasciculate, simple or sometimes branched, septate, hyaline to very pale brown, smooth, up to 25 um long, $2-4 \mathrm{um}$ wide. Conidial secession thexolytic Contia acrogenous, solitary, flattened, one cell thick, broadly ellipsoidal or pyrform in suriace view, narrowly ellipsoidal to clavate in lateral view, 34-56 $\times 24-34 \times 14-18 \mathrm{\mu m}$, smooth, thick-walled, reddish brown to dark brown, murform, with 2 straight columns of vertical septa and $(3-) 4-5(-7)$ rows of transverse septa, slightly constricted at the septa, apical rows of cells darker than the basal rows, dark and thickly banded at the septa, canals in the septa obscured by dark pigmentation, apex comprising a single cell $(9-15 \times 5-7 \mathrm{fm})$, base comprising three thinwalled, pale small cells $(2-3 \times 1.5-2 \mathrm{um})$ in a row.

KNOWN DISTRBUTTON: Kenya.

Note The conidia of this species are the darkest amongst all known species of Canalisporium. The species is unique in hav. ing conidia with three small cells in a row at the base.

Candisporium itallidtum Goh, W.H. Ho \& K.D. Hyde, sp.nov. Figs. $42-48,58$

ETMMoLogy: palldim: in reference to the pale color of the conidia, compared with other known species, which normally have darkly pigmented conidia.

Sporodochia in substrato naturall punctiformia, dispersa, granulata, atrogrisea, usque $200 \mathrm{Hm}$ lata. Mycelium plerumque in substrato immersum, ex hyphis ranosis, septatis, subhyalinis, 1.5-2.5 um latis, laevibus, compositum. Conidiophora micronemata vel semi-macronemala, mononemata, fasciculata, simplicia vel sparse tamosa, laevia, hyalina vel subhyalina, usque 25 um longa, $2-3$ um lata. Cellulae conidiogenae in conidiophoris incorporatae, teminales, deteminatae, cylindricae vel lenter vesiculosae. Conidia $25-39 \times$ $(15-16-20(-22) \times 8-10 \mu m$, acrogena, solitaria, complanata, laevia, in conspectis superficialibus plus minusve ellipsoidea vel obovoidea, leniter curvata, in conspectis lateralibus cylindrica vel late clavata, pallide olivacea vel pallidissime olivaceobrunnea, muriformia, plenmque cum septis longitudinalibus uniseralis et 45 septis transversis in ordinem, non vitatis, tenuis praedita, interdum cum 1-2 septis verticalis additis praedita, lumina cellularum canaliculis conspicue connexa, cellula basali cuneifomia, subhyalina, tenuitunicata. 2.5-3.5. $\mathrm{\mu m}$ lata, conidiorim secessio thexolytica.

HoLorypus: HONG KONG, New Territories, Tai Po, Tai Po Kau Country Park, on submerged wood, 29 Dec. 1996, W.H. Ho, HKUMM 5903.

Sporodochia on natural substrate punctiform, scattered, granular, dark grey, up to 200 im wide. Mycelium mostly immersed in the substrate, composed of branched, septate, subhyaline, 1.5-2.5 um wide, smooth hyphae Conidiophores micronematous or semi-macronematous, mononematous, fasciculate, simple or sparsely branched, smooth, hyaline or subhyaline, up to 25 um long and $2-3 \mathrm{\mu m}$ wide. Conidiogenous cells integrated, terminal, deteminate, cylindrical or slightly vesiculate. Conidial secession thexolytic. Conidia $25-39 \times$ (15-)16-20 -22$) \times 8-10 \mu \mathrm{m}$, acrogenous, solitary, one-cel! thick and flattened, smooth, more or less ellipsoidal or obovoid in surface view, slightly curved, cylindrical or broadly clavate in lateral view, pale olivaceous or very pale olivaceous brown, muriform, mostly with a slightly curved column of vertical septa and 4-5 rows of transverse septa, occasionally one or two of the central rows of cells may have additional $1-2$ vertical 


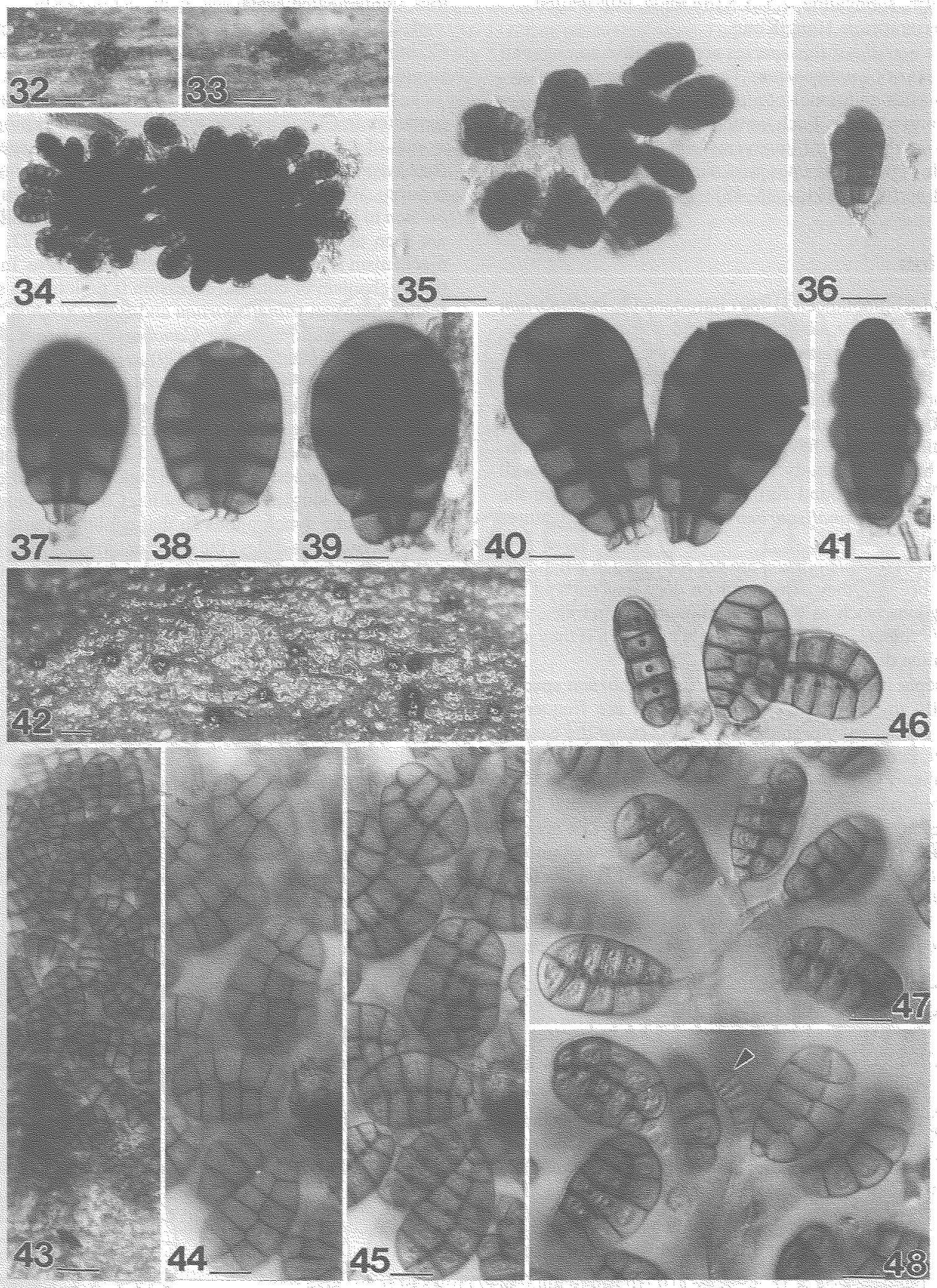


septa, septa unpigmented, thin and canals clearly visible, basal cell cuneiform, subhyaline, $2.5-3.5 \mu \mathrm{m}$ wide, thin-walled.

RNOWN DisTRriution: Hong Kong.

Nore: The conidia of this species are the palest amongst all known species of Canalisporium. The species is unique in having conidia with additional vertical septa besides the single, central column of septa. Each vertical septum is perforated by a canal. Along the rows of transverse septa, only those on the concave side of the conidia possess canals; those on the convex side are not perforated (Figs. $45-48$ ).

\section{Discussion}

Nawawi and Kuthubutheen (1989) introduced Canalisporitm based on $C$. caribense, $C$ pulchtm, and $C$. elegans, species that have several common characters. They are all lignicolous with black, punctiform, nonstromatic sporodochia, which contain muriform conidia that are complanate, generally brown, and have longtudinal and horizontal rows of septa that are darkly pigmented. They have a single basal cell that is delinited from the conidial body in pigmentation, size, and wall thickness. We have found further features that broaden the generic concept of Canalisporium and some of these features are noted below.

1. Species of Canalisporium are not restricted to a lignicolous habitat because they also occur on decaying parts of the monocotyledons, such as bamboo culms, palm rachides, and leaves of Freycinetia and Pandonus. It is unknown if they also occur on fallen dicotyledonous leaves:

2. The septa in the conidia of most Canalisporium species are generally thickly banded and the canals are frequently obscured by this heavy pigmentation. This is not the case in C. pallidtm, because the conidia are pale with clear septation and conspicuous canals.

3. The ordered arrangentent of septa in the conidal body and the presence of septal canals in all Canolisporium species is unique amongst taxa of Hyphonycetes. We have examined the type material of Berkleasmium leonense M.B. Elis ( $L M$ 103399 a), the condia of which are composed of three-seriate cells (Ellis 1976) and similar to hose of C puchrmi. Berkleasminm leonense, however, is not a Canalisporim because its conidia lack septal canals, although the conidia are pale with thin, unpigmented septa.

4. The three smaller cells at the base of the conidia in C. kervense are extraordinary, because most species have a single basal cell.

5. Nawawi and Kuthubutheen (1989) noted that conidial secession in Canalisportum was schizolytic and proposed this as one of the criteria separating Canalisporium species from Berkleasmim, which apparenty has thexolytic conidial secession. We have observed conidial secession in Canatisporiwn to be thexolytic because minute frills of wall remnants are seen at the base of the conidia (Figs. 11, 22, 31). This mechanism is also seen in Berkleasmitm leonese. In this case, the mechanism of conidial secession is no longer a separating feature between Canalisporium and Berkleasmium.

6. The conidiophores in Canolisporim are described by Nawawi and Kuthubutheen (1989) as semi-macronematous to macronematous: We have observed the conidiophores to be hypha-like (micronematous) or barely distinguishable from vegetative hyphae (semi-macronematous). They are normally aggregated in a loose fascicle (Fig. 17), The conidiophores are initially more or less cylindrical (Figs. 47,48) and eventually give rise to a single crop of conidia. Conidium ontogeny and maturation are synchronous so that conidia from each sporodochium are more or less the same in terms of size, number of cells, and pigmentation. Developing conidia are normally embedded in a hyaline gelatinous sheath that may persist when the condia mature. No proliferation is seen in the conidiophores. When the conidia mature, the hypha-like conidiophores swell and the cells become vesiculate (Figs. 2, 5, 7, 24). These swollen cells eventually disintegrate and the crop of mature conidia are released Occasionally, one or more of these vesiculate cells may still be attached to the base of the conidia after conidial secession (Figs. $3,6,25,26)$. This phenomenon, however, is more frequently encountered in $C$. canbense Detached conidia that occasionally or consistently bear one or more vesiculate cells at the base are also seen in other hyphomycetes, e.g, Berkleasmium corticola (Karst.) Moore (Sharma 1980), Dictyosporitm gannii Bhat and Sutton (1985), Monodictys paradoxa (Corda) S. Hughes (Hughes 1951), and Oncopodiun antonioe Sacc. (Ellis 1971). Whether this character is the result of conidogenesis and conidial se-

\section{Key to species of Canalisporim}

1a. Conidia with three distnet small cells in a row at the base and a single cell at the apex......................C. kenyense

1b. Conidia with a single basal cell and one (rarely), two or more cells in a row at the apex..... .2

$2 a$. Condia with a single column of vertical septa but occasionally with a few additional, scattered, vertical septa, pale, olvaccous with clearly visible septa and canals, septa thin and not banded........................................... C. pallidum

$2 b$. Condia with a single, double, or 45 column(s) of vertical septa, pale brown to dark brown, septa usually thick



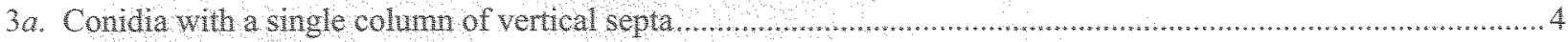

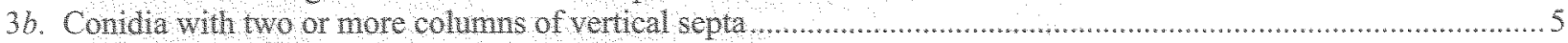

4a. Conidia $24-51 \times 15-29 \times(8-) 10-16$ um, with $3-6(-7)$ rows of transverse septa ............................. caribense

4b. Conidia 18-25 $\times 13-15 \times 5-8$ um, with $2-3(-4)$ rows of transverse septa ............................................ exigutum

5a. Conidia regularly with 2 columns of vertical septa, $25-63 \times(16-) 20-32 \times 12-17 \mu m \ldots \ldots \ldots \ldots \ldots \ldots . . .$. C. pulchmm

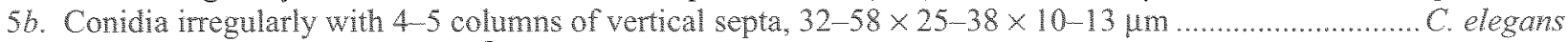




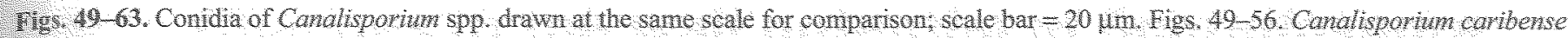

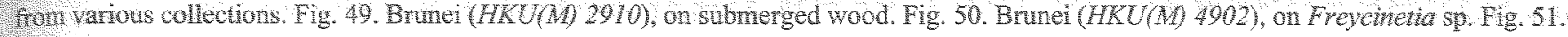

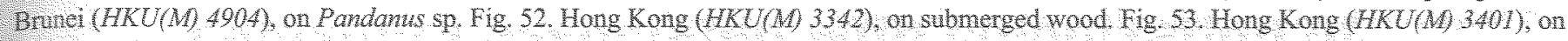

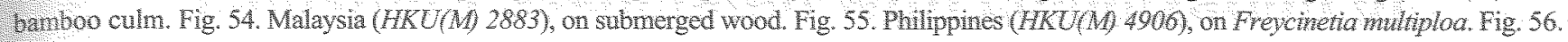

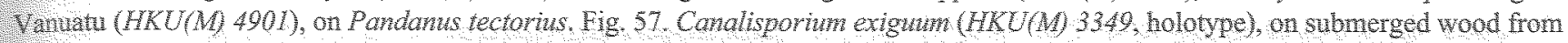

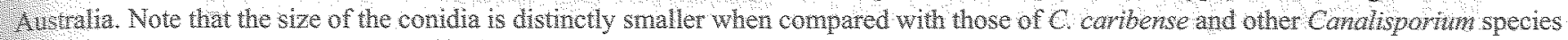

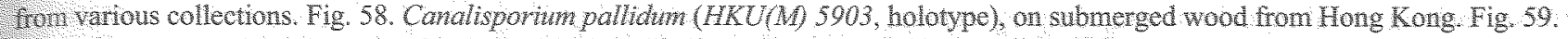

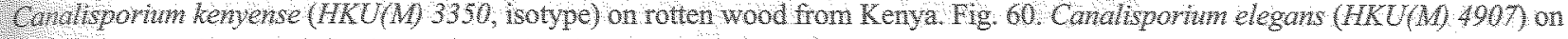

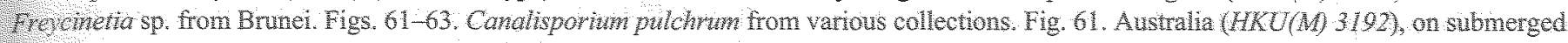

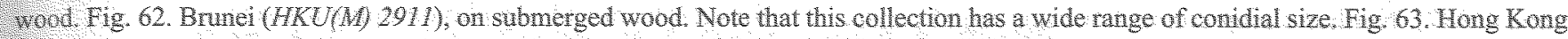
(WT044 44), on submerged wood.
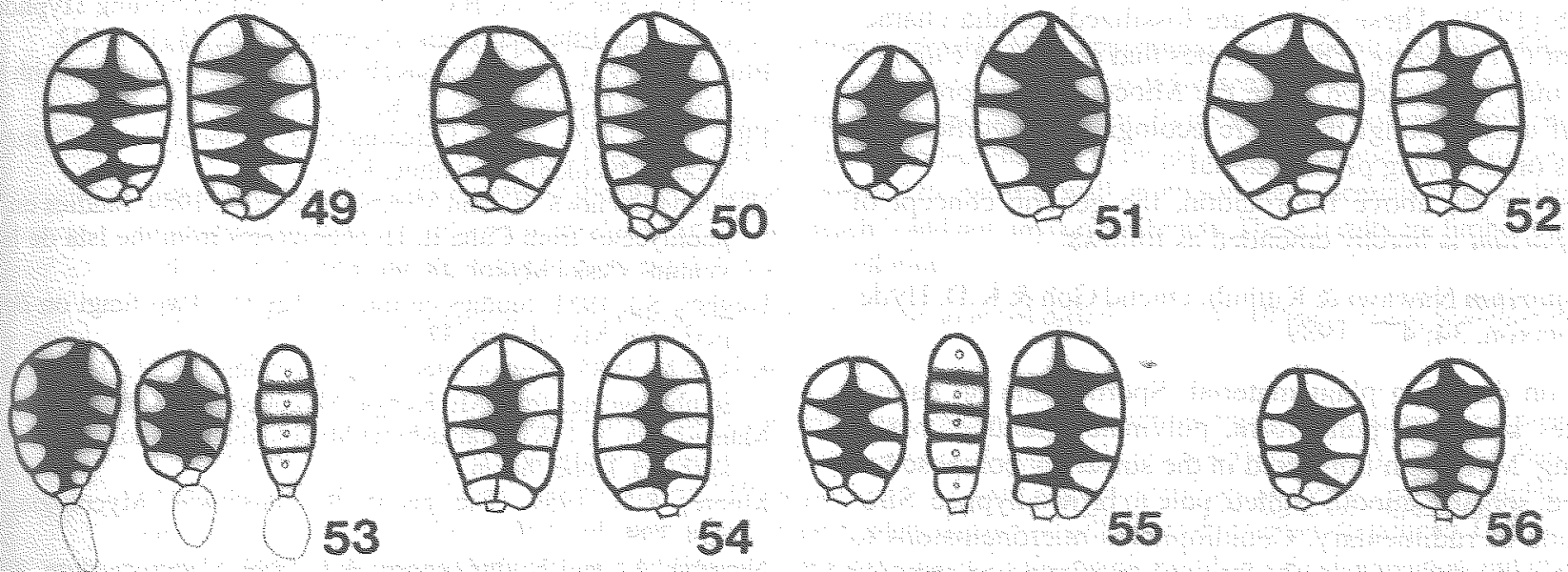

54
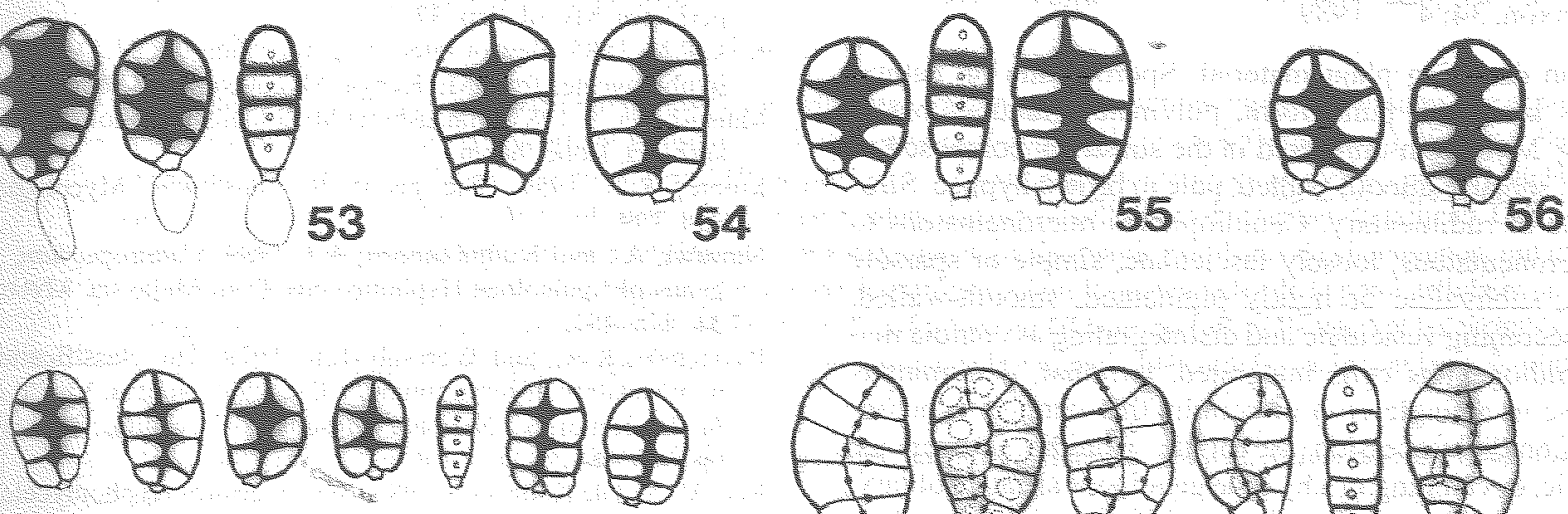

57
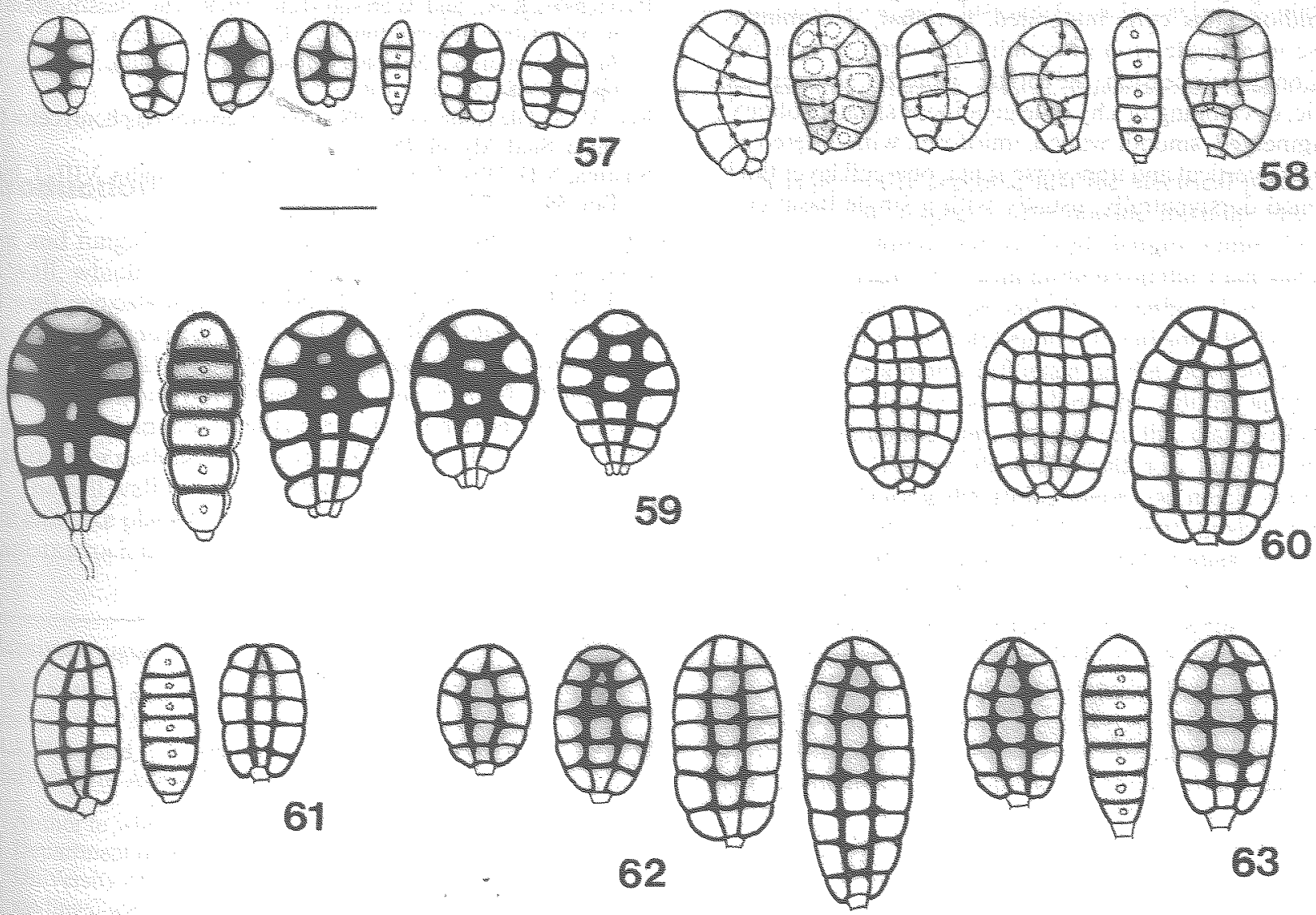

62

63 
cession similar to that found in Canalisporim species awaits further observations.

7. Species of Canalisporim have been successfully grown in pure culture (Matsushima 1987; Nawawi and Kuthubutheen 1989). We have also obtained several isolates of $C_{\text {. }}$ caribense from owr collections. The colonies are slow-growing, dark brown, effuse, lacking aerial mycelium and comprise septate, straight, moderately branched, dark olivaceous, smooth hym phae. Chlamydospores in culture have been reported by Matsushima (1987). Neither clamp connections nor septal canals have been observed in the mycelium.

8. Fossilized spores of Pleospora farlowiana Rehm and an unnamed fossilized fungus are illustrated by Pirozynski and Weresul (1979). These spores are fossilized conidia characteristic of $C$ caribense. This indicates that species of Candlsporium may have existed since the Miocene and represent a group of ancient fungi that were ecologically significant as saprobes on decaying plant material.

Based on the above information, the generic concept of Canalisporim is hereby emended as follows:

Candisportun Nawawi \& Kuthub. emend Goh \& K.D. Hyde. Mycotaxon, $34: 477.1989$

Habitat on decaying plant material. Sporodochia on natural substrates scattered, punctiform, puivinate, granular, black, glistening. Mycelium immersed in the substrata, composed of branched, septate, smooth-walled, pale to brown hyphae. Stromata none or rudimentary. Conidiophores micronematous to semi-macronematous, loosely fasciculate, simple or sparsely branched, subhyaline or lightly pigmented, smooth-walled, septate, beconing vesiculate and disintegrating as conidia mature. Conidiogenous cells integrated, terminal, determinate, giving rise to a single crop of conidia that matures synchronously. Conidial secession thexolytic. Conidia acrogenous, holoblastic, developing in a hyalme gelatinous sheath, solitary, pale or pigmented, smooth-walled, muriform, with ordered arrangement of vertical and transverse septa, one-cell layer thick and lattened dorsiventrally, usually with a single basal cell, but one with three small cells at the base. Cell lumen connected by septal canals that are normally barrel shaped and pigmented.

\section{Acknowiedgments}

We are grateful to Herb. IMI for loaning us type material of Berhleasmim pulchnm and Berkleasmium leonense. Beatrice Tread, Helen Leung, Ken Wong, and A.Y.P. Lee are thanked for their technical and photographic assistance.

\section{Peferences}

Bhat, D., and Sutton, B.C. 1985 . New and interesting Hyphomycetes Pom Ethopa, Trans. Br. Mycol. Soc. 85: $107 / 22$.

Ells, MD . 1971. Dematiacous Hyphonycetes. Commonwealth Mycologion Instute, Kew, U.K.

Ells, MP 1976. More Denatiaceous Myphomycetes Commonwealh M/ycological Insthtute, Kew, U.K.

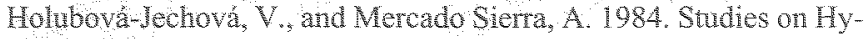
phomycetes from Cube $M$. Myphomycetes from the Isla de la Juventud. Ceská Mykol. 38: 96-120.

Haghes, S.Y. 1951. Studies or microfungi. W. Two fungi on Betula periderm. Mycol. Pap. 37: 1-17

Kirk. P.M. 1985. New or interesting microrngi. XV. Dematiaceous hyphomycetes from Mt. Kenya. Mycotaxon, 23: 305-352.

Matsushma, T. 1987 Matsushma Mycological Memoir, No, 5. Matsushima, Kobe, Japar.

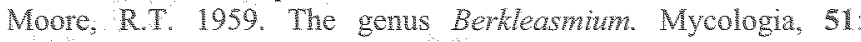
734739.

Nawawi, A., and Kuthubutheen, A.Y. 1989. Canalsporim, a new genus of Ingicolous Hyphomycetes Hom Malaysia. Mycotaxon, 34: 475487 .

Prozynsk, K.A., and Weresub, L.K. 1979. The classification and nomenclature of fossil tungi. The whole fungus. Vol 2. Edied by B. Kendrick National Museum of Canada, Ottawa, Ond pp. $658-688$.

Rao, V., and de Hoog, G.S. 1986. New or critcal Hyphonycetes fron india. Smo. Mycol, $28:$ : -84 .

Shama, N.D. 1980. Some additions to fungi of India. VII. I. Indian Bot. $59: 72-77$. 